\title{
Productivity of Lotus corniculatus and L. pedunculatus cultivars with and without tall fescue under sheep grazing
}

\author{
K.H. WIDDUP ${ }^{1}$, W. RUMBALL ${ }^{2}$, M.P. ROLSTON ${ }^{1}$ and B.J. ARCHIE ${ }^{1}$ \\ ${ }^{1}$ AgResearch, Canterbury Agriculture and Science Centre, P.O. Box 60, Lincoln \\ ${ }^{2}$ AgResearch, Grasslands Research Centre, PB 11008, Palmerston North \\ keith.widdup@agresearch.co.nz
}

\begin{abstract}
The nutritional benefits of condensed tannin (CT) in forages such as Lotus are known but difficulties with establishment, herbage production and persistence in a pasture have hindered farmer uptake of this valuable legume. A sheep grazing experiment was established to investigate the effects of growing three Lotus corniculatus (Grasslands Goldie, G46 and Creeping) and two L. pedunculatus (Grasslands Maku and Grasslands Trojan) cultivars with or without Grasslands Advance tall fescue (Schedonorus phoenix syn. Festuca arundinacea) and with or without white clover (Trifolium repens) under infrequent (8-weekly) grazing. Without grass, the content of $L$. corniculatus and $L$. pedunculatus in the swards was $85 \%$ and $60 \%$ respectively by year 3 . Adding white clover reduced the Lotus content in the swards by $20 \%$. With tall fescue, the L. corniculatus cultivars increased from 6 to $34 \%$ between the summer of year 2 and year 3 . In contrast, the L. pedunculatus cultivars remained at very low 1$2 \%$ levels in the summer of both years. Inclusion of white clover did not further reduce Lotus content in the tall fescue swards.

While there was no significant difference in content and yield between $L$. corniculatus cultivars, there was a consistent trend for Goldie to produce more herbage. Goldie had the potential to produce $2 \mathrm{t}$ dry matter (DM)/ ha/year in a mixed pasture with tall fescue under infrequent grazing. Creeping L. corniculatus contained higher CT levels than Goldie (3.5 cf.1.1\% of herbage DM respectively) and is thus potentially able to provide greater amounts of CT in a pasture. Trojan and Maku $L$. pedunculatus had similar plant density and herbage productivity. The experiment will be monitored further to determine the long-term persistence of these Lotus cultivars in a mixed pasture.
\end{abstract}

Keywords: condensed tannins, infrequent grazing, legume composition, Lotus corniculatus, L. pedunculatus, tall fescue, white clover

\section{Introduction}

The use of Lotus species such as Lotus corniculatus and $L$. pedunculatus as a quality forage for grazing animals has been promoted for some time. The benefits have been linked to the occurrence of condensed tannins in the herbage which have resulted in improved liveweight gains, wool weight and ovulation rate in sheep (Douglas et al. 1995; Waghorn et al. 1998; Barry et al. 2003) and sometimes to a reduction in gastrointestinal worm numbers (Niezen et al. 1995). However, Lotus species are difficult to establish and manage in a grazed pasture and for that reason, $L$. corniculatus has been mainly promoted for use in drier regions in pure stands (Barry et al. 2003). In moist, high fertility situations where perennial ryegrass and white clover are present, L. pedunculatus is uncompetitive resulting in poor growth and persistence (Brock et al. 1978)

AgResearch Grasslands has recently produced a selection of L. corniculatus named Creeping, which develops large numbers of shoots with a prostrate growth habit designed to improve persistence with grasses in a grazed situation (W. Rumball unpublished). Creeping has also been selected for higher levels of condensed tannins in the herbage than are available in the current cultivars of this species. A new tetraploid $L$. pedunculatus cultivar named Trojan, selected for improved establishment vigour compared with Maku, has recently been released. This new plant material warrants closer examination under grazing in a pasture compared to current commercial material to determine whether improvements in establishment and persistence have occurred. Also, with the objective of developing a more compatible sward for Lotus species, the slower establishing tall fescue may be a better companion grass with Lotus in a pasture rather than the more competitive perennial ryegrass.

This paper reports on the performance of five Lotus cultivars grown either in monoculture or in a pasture with tall fescue, with or without associated white clover under infrequent grazing with sheep.

\section{Material and methods Experimental design}

The field experiment was sown into a cultivated seedbed on 12 October 2001 at the AgResearch Lincoln Farm in Canterbury (lat. $43^{\circ} 38^{\prime} \mathrm{S}$ ) on a Wakanui silt loam. The experimental design was a randomised splitsplit block with four replications. The main plots (2) measured $40 \mathrm{~m}$ x $5.4 \mathrm{~m}$ either with no-grass or Advance 
tall fescue drilled at $15 \mathrm{~kg} / \mathrm{ha}$. The sub plots (5) measured $8 \mathrm{~m} \times 5.4 \mathrm{~m}$ and consisted of three $L$. corniculatus cultivars: Goldie, G46 (a selection bred for the South Island high country), Creeping and two $L$. pedunculatus cultivars; Maku and Trojan. Seed of each Lotus cultivar was slurry inoculated with the appropriate Rhizobium and broadcast sown at $8 \mathrm{~kg} / \mathrm{ha}$. The sub-sub plots (2) measured $8 \mathrm{~m} \times 2.7 \mathrm{~m}$ and were broadcast sown with or without Demand white clover at $1 \mathrm{~kg} / \mathrm{ha}$. All plots were chain harrowed to cover the seed. These combinations of Lotus in monoculture, with white clover and/or tall fescue, were designed to provide a range of levels of sward competition.

\section{Management}

During the November-January 2001 establishment period, flumetsulam (Preside at $65 \mathrm{~g} / \mathrm{ha}$ ), diflufenican + promoxinil (Jaguar at 1 1/ha) and 2,4-DB (3 1/ha) were applied to control dicotyledon weeds. The experimental area was mechanically topped in December 2001 and received a fertiliser dressing with Cropmaster 15 (NPKS 15:10:10:8) applied at $200 \mathrm{~kg} / \mathrm{ha}$ with a repeat dressing in April 2002. The first grazing occurred in February 2002, 18 weeks after sowing. Volunteer white clover in the no clover sub plots was controlled with ethofumesate (Nortron at $1.5 \mathrm{l} / \mathrm{ha}$ ) in August 2002 and October 2003. Grass weeds in the no-grass plots were controlled with haloxyfop (Gallant at $1.51 / \mathrm{ha}$ ) in August 2002 and with propyzamide (Kerb at 1.51 1/ha) in July 2003. The experiment was irrigated with $50 \mathrm{~mm}$ of water in November and February of each year. The experiment was grazed infrequently with sheep (about every 8 weeks) in September, November, January, March and June of each year. The tall fescue plots were topped in October and December each year to remove reproductive stem material and encourage vegetative growth.

\section{Measurements}

The plant population was measured from two $0.25 \mathrm{~m}^{2}$ quadrats per plot in April 2002. Herbage assessments started in November 2002 when the botanical composition (percentage of grass, Lotus, clover and weeds) of each plot was visually assessed before each grazing. In November (spring) and March (autumn) of year 2 and year 3, dry matter (DM) yield and botanical composition were determined from two $0.25 \mathrm{~m}^{2}$ quadrats cut from all plots. Samples were oven dried with forced-air at $80^{\circ} \mathrm{C}$. All data were analysed using the Genstat 7 statistical package and where interactions were non-significant, only the main effects were presented. Treatment means were separated using least significant difference at a $5 \%$ probability level $\left(\mathrm{LSD}_{0.05}\right)$.
Table 1 The effects of grass, Lotus and grass $x$ clover treatments on the number of Lotus plants $/ \mathrm{m}^{2}$ at 25 weeks from sowing.

\begin{tabular}{|c|c|c|}
\hline & & $\begin{array}{c}\text { Lotus } \\
\left.\text { (plants } / \mathrm{m}^{2}\right)\end{array}$ \\
\hline \multicolumn{3}{|l|}{ Grass (G) } \\
\hline No-grass & & 41 \\
\hline Tall fescue & & 19 \\
\hline $\operatorname{LSD}_{G}(5 \%)$ & & 4 \\
\hline \multicolumn{3}{|l|}{ Lotus (L) } \\
\hline Goldie & & 38 \\
\hline Creeping & & 44 \\
\hline G46 & & 29 \\
\hline Maku & & 17 \\
\hline Trojan & & 23 \\
\hline LSD (5\%) & & 9 \\
\hline \multicolumn{3}{|c|}{ Grass x Clover (C) } \\
\hline No-grass & No clover & 45 \\
\hline No-grass & White clover & 38 \\
\hline Tall Fescue & No clover & 18 \\
\hline Tall Fescue & White clover & 20 \\
\hline $\operatorname{LSD}_{\mathrm{G} \times \mathrm{C}}(5 \%)$ & & 4 \\
\hline
\end{tabular}

\section{Results}

Six months after sowing, the Lotus plant population in the no-grass treatments had twice the density of those in the tall fescue treatments (Table 1). There was a significant difference between species with $L$. corniculatus (except G46) establishing more plants than the L. pedunculatus cultivars. There was no significant difference between the L. pedunculatus cultivars Trojan and Maku. White clover significantly reduced the Lotus plant numbers in the no-grass plots but did not further reduce Lotus plant numbers in the tall fescue plots.

The first year (October 2001-September 2002) was considered the establishment year, with herbage measurements taken in Year 2 and Year 3. The spring and autumn Lotus and total herbage yields of swards with and without tall fescue are shown in Table 2. While there were no summer yield assessments, the data provides some indication of the potential Lotus and total herbage yield. In the no-grass treatments, the $L$. corniculatus cultivars produced three times the Lotus herbage yield compared with L. pedunculatus cultivars in Year 2 and twice the yield in Year 3. The total herbage yields were also significantly greater in the $L$. corniculatus than the L. pedunculatus swards except in the autumn of Year 3 . The L. corniculatus cultivars had similar herbage yields except that Goldie was superior to Creeping in the autumn of both years. Herbage yields of Trojan and Maku did not differ significantly.

In the tall fescue swards, the relative differences between Lotus cultivars were similar to the no-grass treatment. The Lotus yields of Goldie were similar to the 
Table 2 The seasonal Lotus and total herbage yield ( $\mathrm{kg} \mathrm{DM} / \mathrm{ha}$ ) of the swards with L. corniculatus and L. pedunculatus cultivars growing without grass or with tall fescue over Year 2 and Year 3.

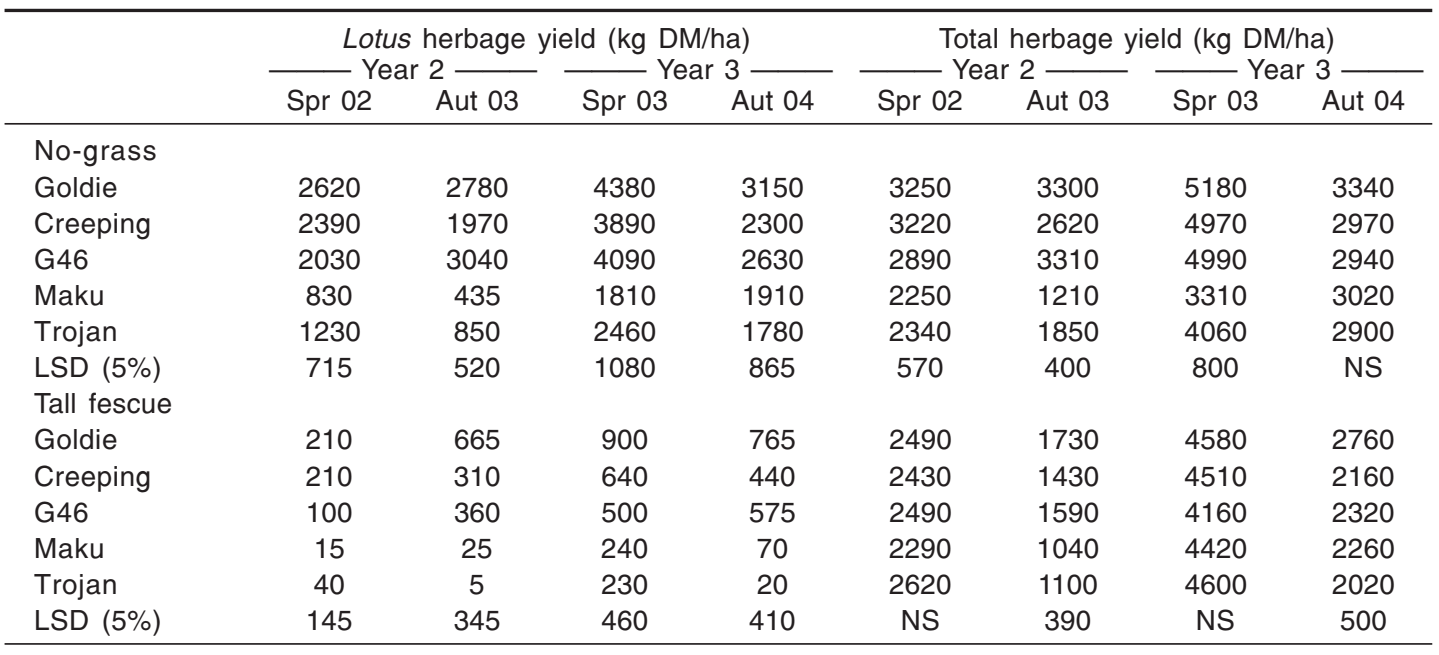

NS non-significantly different

other $L$. corniculatus cultivars but consistently better than the L. pedunculatus cultivars. All Lotus cultivars showed a marked improvement in yield between Year 2 and Year 3. Total sward yields from the Lotus cultivars were similar in the spring of both years but Goldiebased swards had greater autumn yields. Goldie showed the potential to produce $2 \mathrm{t} / \mathrm{h}$ o of Lotus herbage in the tall fescue sward during Year 3, whereas Trojan produced less than $0.5 \mathrm{t} /$ ha by the third year (Table 2 ).

The $\%$ Lotus from plots with and without tall fescue is shown in Figure 1. During the spring/summer/ autumn period, the $L$. corniculatus cultivars maintained $80-90 \%$ content in the no-grass plots compared with 40$60 \%$ content for the $L$. pedunculatus cultivars, with the remainder being weeds and white clover. In the tall fescue plots, the L. corniculatus cultivars made up $6 \%$ of the herbage in the spring of Year 2 but increased to $34 \%$ by the summer of Year 3 (Figure 1). L. pedunculatus cultivars in the tall fescue plots produced less than $1 \%$ of the herbage in Year 2 and remained at a low $2 \%$ level by the summer of Year 3 .

In L. corniculatus, Goldie, Creeping and G46 produced similar amounts of herbage (Figure 2, Table 2) except for Creeping with significantly lower autumn production than Goldie in each year. The $L$. pedunculatus cultivars were significantly poorer than the $L$. corniculatus cultivars throughout the year except in the winter, with no significant difference between Maku and Trojan (Figure 2).

White clover had a greater competitive effect on Lotus in the no-grass treatment by reducing the Lotus content by $15-20 \%$ throughout the season, compared to the tall fescue treatment where Lotus content was unaffected by the presence of clover (Figure 3).

\section{Discussion}

In monoculture, the L. corniculatus cultivars established an adequate plant density whereas the L. pedunculatus cultivars had poor establishment compared with other studies (Bologna et al. 1996; Brock et al. 1978). Low plant numbers may have resulted from the use of herbicides six weeks after sowing to control dicotyledon weeds. These herbicides checked the development of the young Lotus seedlings and caused some seedling mortality. However, under the infrequent grazing management of this experiment, the Lotus content and herbage yields of the L. corniculatus cultivars steadily increased such that the potential Lotus yield in the third year was equivalent to $10-12 \mathrm{t} / \mathrm{ha}$ (including an estimate for summer production). In contrast, the $L$. pedunculatus cultivars had fewer plants and suffered from white clover and weed competition, resulting in low Lotus content and herbage yields half those of the $L$. corniculatus cultivars.

In the tall fescue swards, both Lotus species had low plant density but this had a greater detrimental impact on herbage yields from $L$. pedunculatus than $L$. corniculatus cultivars. Earlier research has shown the poor competitive ability of $L$. pedunculatus in a mixed sward with white clover and ryegrass under high fertility conditions (Brock et al. 1978; Sheath 1981). In this study, the associated slower establishing and less competitive tall fescue together with infrequent grazing management still failed to improve the Lotus content of the L. pedunculatus based swards.

The performance of L. corniculatus in association 
Figure 1 The \% Lotus herbage of the L. corniculatus cultivars growing either without grass ( $-\longrightarrow$ ) or with tall fescue (---O---) and $L$. pedunculatus cultivars growing without grass $(-\square)$ or with tall fescue $(---\square---)$. The bars indicate LSD $(P<0.05)$.

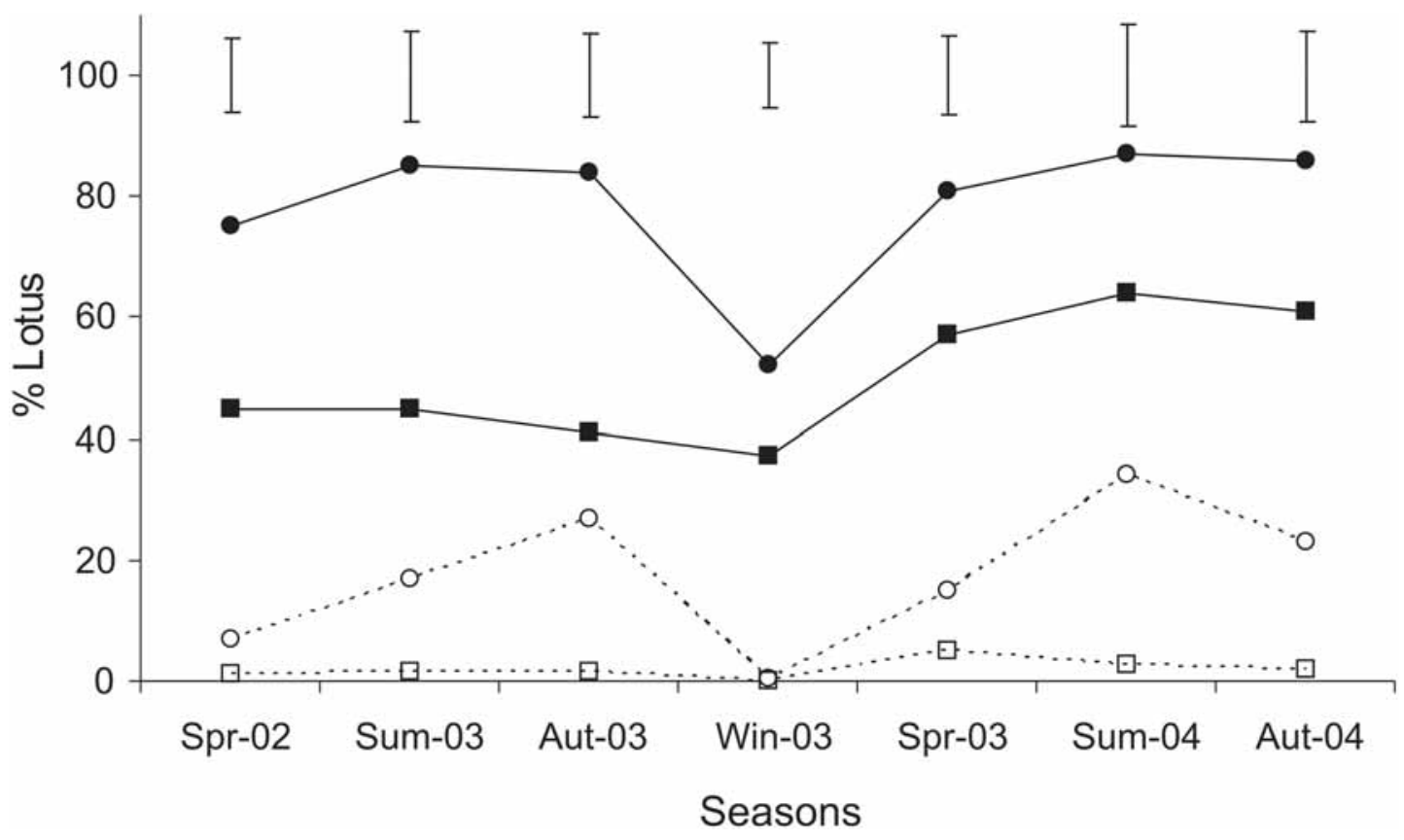

Figure 2 The \% Lotus herbage of the L. corniculatus cultivars, Goldie (- - - ), G46 (- - - ) and Creeping $(-)$ and the L. pedunculatus cultivars, Maku (---O---) and Trojan (--- $\square---)$ averaged over the nograss and tall fescue treatments. The bars indicate LSD $(P<0.05)$.

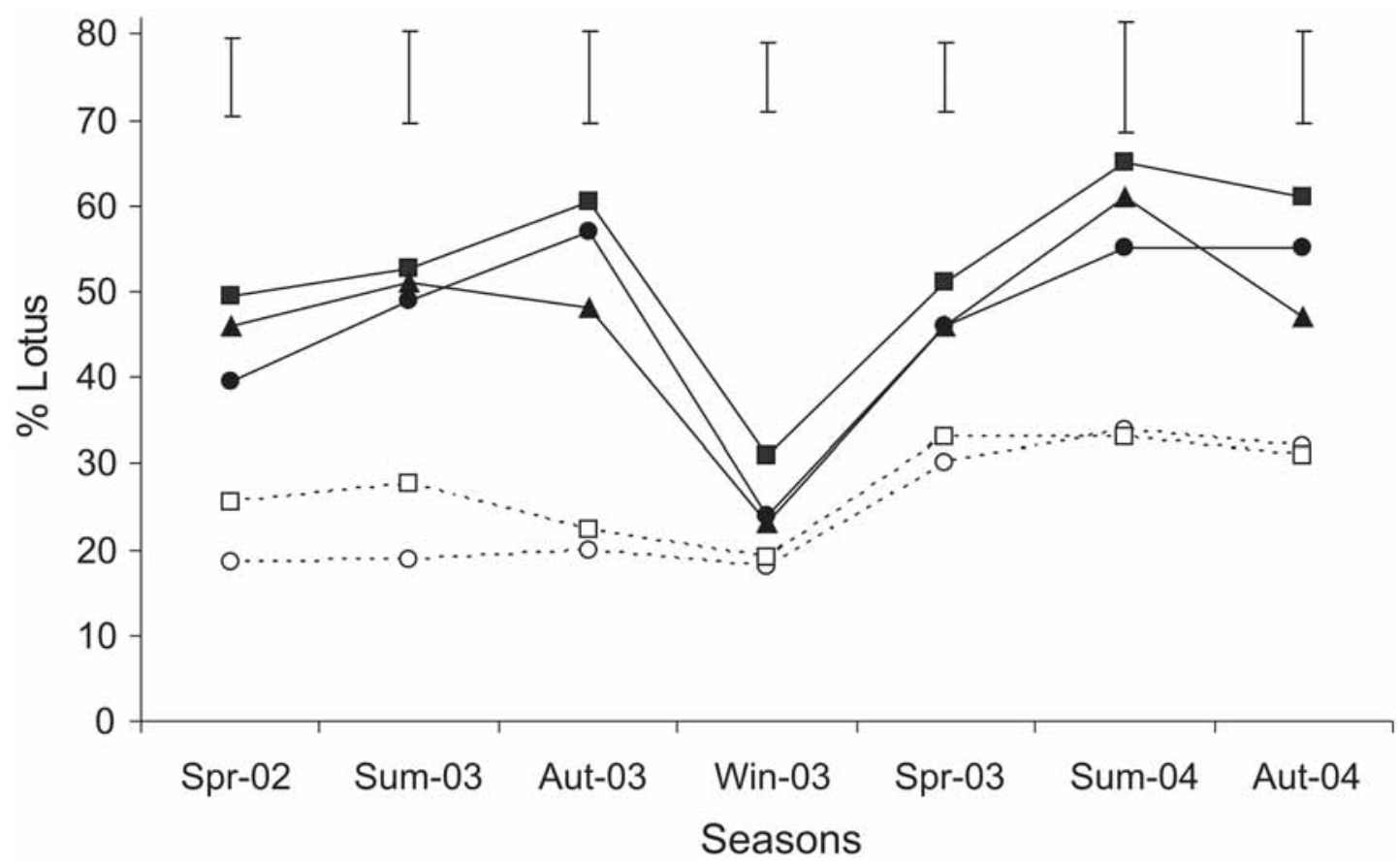


Figure 3 The \% Lotus herbage in the sward of 5 Lotus cultivars growing without grass but either with white clover (- - ) or without white clover (- - ), and growing with tall fescue either with white clover --- $\square$--- or without white clover (---O---). The bars indicate LSD $(P<0.05)$.

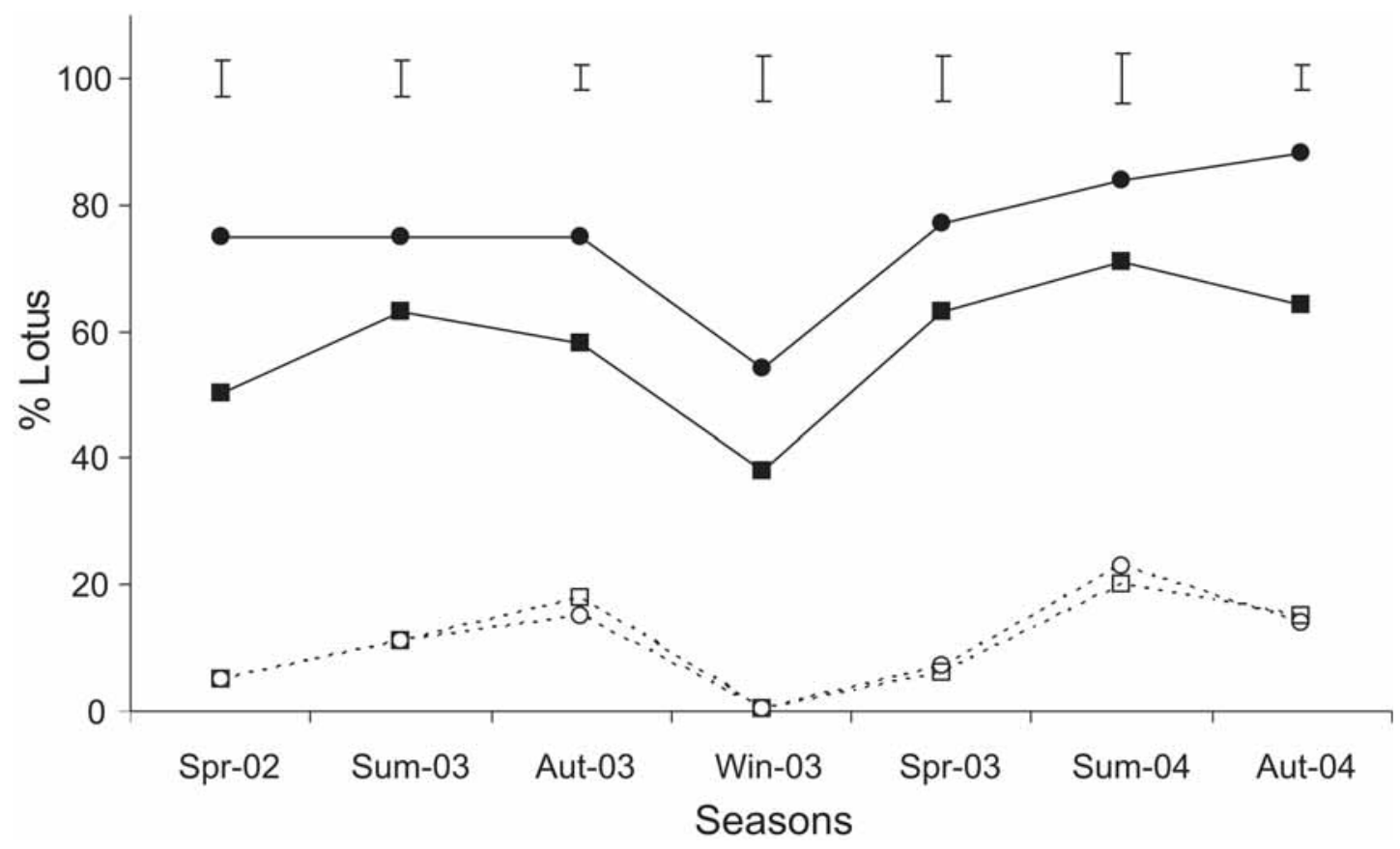

with grass has been much better than L. pedunculatus. New Zealand researchers have promoted the use of $L$. corniculatus in pure stands to achieve high legume yields and better persistence and have discouraged its use in mixed pastures (Barry et al. 2003; RamirezRestrepo et al. 2003; Waghorn et al. 1998). However in this study, the L. corniculatus cultivars developed 20 and $34 \%$ Lotus content in the tall fescue swards by the second and third summers respectively. The combination of infrequent grazing, occasional topping in spring and early summer and the association with less competitive tall fescue, has collectively enabled $L$. corniculatus to produce and persist well in a mixed pasture situation.

A major objective of the experiment was to determine whether the new Lotus cultivars were more competitive and persistent in a pasture situation than the old cultivars. To date, Goldie, G46 and Creeping have produced similar herbage yield, but the denser lowgrowing habit of Creeping may improve its persistence in a grass sward over time. In addition, the seasonal growth pattern of Creeping being concentrated in spring-summer with less late autumn-winter growth than Goldie, may assist with its long-term productivity and persistence. G46, which was bred for the South Island high country also has a spring-summer growth pattern. Continued monitoring of this experiment will answer some of the persistence related issues.
These results suggest that neither of the $L$. pedunculatus cultivars is adapted for use in a lowland mixed pasture situation, possibly affected by the poor establishment, competition from the tall fescue and by the unsuitability of the 'dryland' environment.

The Lotus herbage in a mixed sward is valuable to grazing animals for the improved nutritional value that is associated with legume herbage containing condensed tannin (CT). In three measurements from a field experiment at Palmerston North through the summer of $2002-2003$, Creeping produced $4.89 \%, 2.19 \%$ and $3.36 \%$ CT of the herbage DM, whereas Goldie produced $0.89 \%, 0.68 \%$ and $1.62 \%$ respectively (Geoff Lane pers. comm.). Therefore, the Creeping selection has a higher potential for providing $\mathrm{CT}$ in the mixed pasture than Goldie. However, at this stage Goldie has produced greater herbage DM than Creeping and G46. If Creeping does improve its productivity relative to Goldie over time, then Creeping could provide greater levels of CT in a pasture.

\section{ACKNOWLEDGEMENTS}

We thank Dr Geoff Lane for providing data on condensed tannin levels of the Lotus herbage.

\section{REFERENCES}

Barry, T.N.; Kemp, P.D.; Ramirez-Restrepo, C.A.; LopezVillalobos, N. 2003. Sheep production and agronomic 
performance of Lotus corniculatus under dryland farming. Legumes for dryland pastures. Grassland Research and Practice Series 11:109-116.

Bologna, J.J.; Rowarth, J.S.; Fraser, T.J.; Hill, G.D.1996. Management of birdsfoot trefoil (Lotus corniculatus L.) pastures for productivity and persistence. Proceedings of the Agronomy Society of New Zealand 26:17-21.

Brock J.L.; Charlton, J.F.L. 1978. Lotus pedunculatus establishment in intensive farming. Proceedings of the New Zealand Grassland Association 39: 121-129.

Douglas, G.B.; Wang,Y.; Waghorn, G.C.; Barry, T.N.; Purchas, R.W.; Foote, A.G.; Wilson, G.F. 1995. Liveweight gain and wool production of sheep grazing Lotus corniculatus and lucerne. New Zealand Journal of Agricultural Research 38: 95-104.

Niezen, J.H.; Waghorn, T.S.; Charleston, W.A.G.; Waghorn, G.C. 1995. Growth and gastrointestinal nematode parasitism in lambs grazing either lucerne (Medicago sativa) or Sulla (Hedysarum coronarium) which contain condensed tannins. Journal of Agricultural Science, Cambridge 125: 281-289.

Ramirez-Restrepo, C.A.; Kemp, P.D.; Barry, T.N.; Lopez-Villalobos, N. 2003. Seasonal dry matter production of Lotus corniculatus in a dryland commercial sheep pastoral system. Legumes for dryland pastures. Grassland Research and Practice Series 11:185-188.

Sheath, G.W. 1981. Lotus pedunculatus - An agricultural plant? Proceedings of the New Zealand Grassland Association 42: 160-168.

Waghorn, G.C.; Douglas, G.B.; Neizen, J.H.; McNabb, W.C.; Foote, A.G. 1998. Forages with condensed tannins - their management and nutritive value for ruminants. Proceedings of the New Zealand Grassland Association 60: 89-98. 